\title{
Immobilization of cadmium in soil using magnetic biochar derived from Eichhornia crassipes
}

\author{
Chompoonut Chaiyaraksa*, Nongnapa Lokham, Rawisara Kuikrong, Sangarun Artsanapaiboon \\ Faculty of Science, King Mongkut's Institute of Technology Ladkrabang, Bangkok 10520 Thailand
}

*Corresponding author, e-mail: kcchompoonut@gmail.com

Received 24 Sep 2019

Accepted 23 Jun 2020

\begin{abstract}
Heavy metal contamination in an environment is a critical problem in Thailand that needs to be addressed urgently, particularly contaminated soil. This research aims to study the adsorption of cadmium ion by unmodified biochar and sodium dodecyl sulfate modified magnetic biochar (SDS-MB) derived from Eichhornia Crassipes. The adsorbent and soil characteristics were determined. Observed by scanning electron microscope (SEM), the surface of unmodified biochar (B) was smoother than SDS-MB. The X-ray diffractometer (XRD) pattern showed peaks for iron oxide. The values of point of zero charge $\left(\mathrm{pH}_{\mathrm{PZC}}\right)$ and acid neutralization capability (ANC) were 3 and $1000.3 \mathrm{meq} / \mathrm{kg}$, respectively. The greatest adsorption of cadmium occurred when the $\mathrm{pH}$ of the wastewater was 8 . The adsorption reached equilibrium within $1 \mathrm{~h}$. It followed Freundlich, Temkin, and Dubinin-Radushkevich isotherm model and the pseudo-second-order kinetic. SDS-MB was mixed with sandy clay loam soil (pH 7.87) contaminated with cadmium $50 \mathrm{mg}$ per kilogram soil at the ratio of $0-5 \%$. The results from the extraction with ethylenediaminetetraacetic acid (EDTA), ammonium acetate, calcium chloride, diethylene triamine pentaacetic acid (DTPA), and sequential extraction method indicated that $5 \%$ mixing ratio showed the best ability to reduce cadmium movement in the soil. Cadmium in a form that bound to oxide and a form that bound to organic matter significantly increased.
\end{abstract}

KEYWORDS: cadmium, Eichhornia crassipes, magnetic biochar, sodium dodecyl sulfate, soil remediation

\section{INTRODUCTION}

Cadmium is commonly found in many products such as Cd-Ni rechargeable batteries, plastics, ceramics, glasses, enamels, polyvinylchloride, cigarettes, electronic applications, electrical conductivity alloys, heat conductivity alloys, electrical contact alloys, and solar cells $[1,2]$. Cadmium has been found contaminated in environments such as near the factory and near the garbage dump. Cadmium is highly toxic. It affects blood, liver, and kidneys and is the cause of the Itai-Itai disease [3,4]. Cadmium contaminated soil is not suitable for agricultural use, but farmers do not have much choice. They need to grow crops while the land is contaminated. The restoration of cadmium contaminated soil is essential and urgent in order to ensure the safety of the health of people who consume plants grown in the contaminated soil. Adsorption techniques help to reduce the transformation of cadmium from the soil into the biological systems $[5,6]$ with high efficiency, affordability and in situ availability. It is a safe alternative to restoring heavy metal contaminated soil [7]. Substances that are added to stabilize metals in soils can be classified into 4 groups as follows: group 1 (inorganic substances such as bentonite, phosphate, lime, gypsum, and zeolite, etc.), group 2 (substances derived from industrial processes such as metal sediment, rods, and fly ash, etc.), group 3 (agricultural wastes such as sawdust, corn core, and bean shell, etc.), group 4 (bio-charcoal produced from agricultural waste). Although adding a metal stabilizer will not remove $\mathrm{Cd}$ from the soil, it can reduce Cd toxicity and human health risk [8]. Water hyacinths are plants that cause environmental, social, and economic problems [9]. It will be an appropriate solution to solve such problems if all sectors help to find the best way to earn benefit from water hyacinths. Previous researchers have experimented by applying water hyacinths to absorb contaminating metals in wastewater $[10,11]$ and to remediate soil [12]. They found that the adsorption efficiency was not good enough. There were other researchers producing biochar by passing water hyacinth through the pyrolysis process. Pyrolysis process converted cellulosic carbons, which tend to decompose in the soil, to more stable and slower decomposable aromatic carbons $[13,14]$. Biochar was brought to treat wastewater. The adsorption efficiency was 
better than that without pyrolysis [15]. Another researcher mixed biochar with sandy soil and investigated Cd adsorption efficiency [16]. The results showed that the higher the mixing ratio of biochar to the soil, the higher the value of $Q_{\mathrm{m}}$ (the maximum amount of adsorbed material per unit mass of sorbent). Some researchers have developed biochar by using many substances such as acid or base, coating with salt or metal oxides and surfactants [17]. At present, attention is focused on making magnetic biochar [18]. Previous researcher has improved the biochar from sorghum straw by making chitosanbiochar $/ \mathrm{Fe}_{2} \mathrm{O}_{3}$ [19]. It can adsorb $\mathrm{Cd}$ ions in the wastewater with $Q_{\mathrm{m}}$ equal to $105.26 \mathrm{mg} / \mathrm{g}$, which is higher than biochar $/ \mathrm{Fe}_{2} \mathrm{O}_{3}$ without chitosan. SDS is another attractive substance to modify magnetic biochar. This research aims to add value to water hyacinths by producing and comparing biochar, biochar $/ \mathrm{Fe}_{2} \mathrm{O}_{3}$, and SDS-biochar $/ \mathrm{Fe}_{2} \mathrm{O}_{3}$ and applying for soil remediation.

\section{MATERIALS AND METHODS}

\section{Preparation of adsorbents}

The method was modified from those previously reported [20,21]. The collection of water hyacinths was from a canal nearby King Mongkut's Institute of Technology Ladkrabang. They were cleaned with water to remove dirt, heated to dry, crushed until they can pass through a $37.5 \mathrm{~mm}$ sieve, passed through a pyrolysis process operating at $400^{\circ} \mathrm{C}$ for $4 \mathrm{~h}$. The product called unmodified biochar (B). After immersing the crushed water hyacinth in $2.5 \mathrm{M}$ $\mathrm{FeCl}_{3}$ for $3 \mathrm{~h}$ and heating at $70^{\circ} \mathrm{C}$ for $0.5 \mathrm{~h}$ and further heating at $400^{\circ} \mathrm{C}$ for $4 \mathrm{~h}$, the magnetic biochar (MB) was a product. The MB was added to $0.01 \mathrm{M} \mathrm{SDS}$, left for $4 \mathrm{~h}$ at $50^{\circ} \mathrm{C}$, filtered through 0.45 -micrometer filter paper, washed with water, and heated to dry at $100^{\circ} \mathrm{C}$ for $24 \mathrm{~h}$. The last product was SDS modified MB (SDS-MB).

\section{Synthetic wastewater preparation}

Preparation of $1000 \mathrm{mg} / \mathrm{l} \mathrm{Cd}$ stock solution was carried out using cadmium (II) nitrate tetrahydrate (AR grade) and double-distilled water. After adjusting the solution $\mathrm{pH}$ to 2 using $0.1 \mathrm{M}$ nitric acid, it was kept at $4^{\circ} \mathrm{C}$ for preservation.

\section{Adsorbent characterization}

The physical characteristics of $\mathrm{B}, \mathrm{MB}$, and SDS-MB was studied using Scanning Electron Microscope (SEM) (1455 VP, Leo), and X-ray Diffractometer (XRD) (D8 Advance, Bruker). The $\mathrm{pH}$ value at the zero-point charges was determined by preparing the $0.01 \mathrm{M} \mathrm{NaCl}$ solution at various $\mathrm{pH}$ values, adding an adsorbent, measuring the solution $\mathrm{pH}$ after shaking for $24 \mathrm{~h}$, and plotting the graph between the initial and final $\mathrm{pH}$ [18]. The value of acid neutralization capability (ANC) was analyzed by titration method [22].

\section{Adsorption experiments}

The experiment was carried out in a batch process by adding an adsorbent to a $500 \mathrm{ml}$ beaker containing $200 \mathrm{ml}$ of cadmium contaminated wastewater. The mixture was stirred at $120 \mathrm{rpm}$ and then filtered. The cadmium concentration in the aliquot was determined by Atomic Adsorption Spectrophotometer (AAS) (AAS200, Perkin Elmer). The system temperature, adsorbent amount, initial cadmium concentration, and initial solution $\mathrm{pH}$ were varied as $30-55^{\circ} \mathrm{C}, 25-700 \mathrm{mg}, 10-40 \mathrm{mg} / 1$, and $\mathrm{pH} 2-9$, respectively.

\section{Isotherm, kinetic, and thermodynamic study}

Table S1 showed all used equations [23-29].

\section{Soil sample}

Soil from Rayong province was collected using the equal interval on the diagonal line method at the soil surface to the depth of $30 \mathrm{~cm}$. The collection was from many points and then mixed. A large piece of debris and weeds were removed from the sampling soil, dried in sunlight, crushed with a mortar, sieved through a 20 mesh sieve, and heated to dry in the oven at $105^{\circ} \mathrm{C}$ for $24 \mathrm{~h}$. Soil characterization was as follows: soil texture (hydrometer), moisture (ASTM 2216), pH (pH meter, Consort C860), electrical conductivity (conductivity meter), cation exchange capacity (Ammonium acetate method), loss of ignition (burning at $550^{\circ} \mathrm{C}$ and calculating the mass loss), organic matter (Walkley-Black titrations method), nitrate ion (Brucine method), chloride ion (Argentometric method), total phosphate (Molybdovanadophosphate method), sulfate ion (Turbidimetric method), aluminium ion (Colorimetric method), major element $\left(\mathrm{Ca}^{2+}, \mathrm{Mg}^{2+}\right.$ and $\mathrm{K}^{+}$) and total heavy metal $\left(\mathrm{Cd}^{2+}\right)$ (SW-846 method 3050b). The soil was prepared to contaminate with cadmium $50 \mathrm{mg} / \mathrm{kg}$. The contaminated soil was left for 3 weeks before mixing with SDS-MB. The contaminated soil was then mixed with SDS-MB at the ratio of $0 \%, 0.5 \%, 1 \%, 2 \%$ and $5 \%$ and further left for 2 weeks. Determination of heavy metal moving in the environment was by single-step extraction with $0.005 \mathrm{M}$ diethylenetriaminepentaacetic acid 

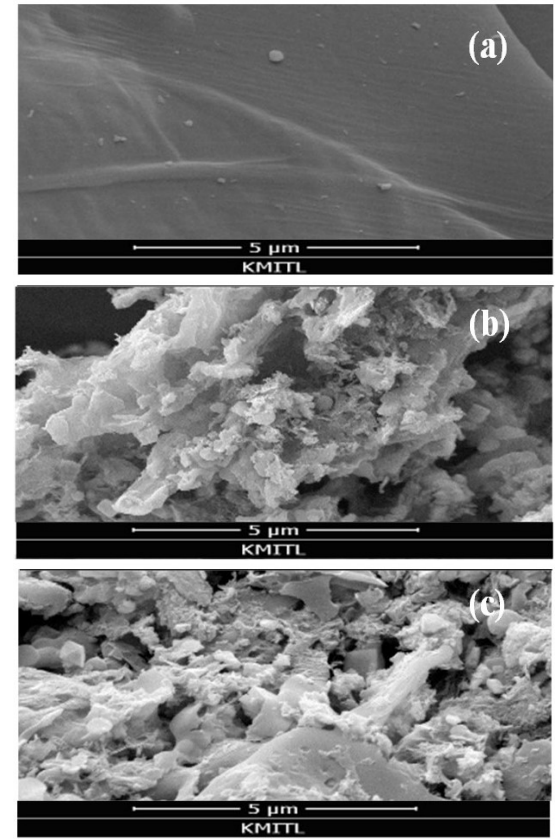

Fig. 1 SEM images of (a) B, (b) MB, and (c) SDS-MB.

(DTPA), $0.01 \mathrm{M} \mathrm{CaCl}_{2}, 0.05 \mathrm{M}$ ethylenediaminetetraacetic acid (EDTA) and $1 \mathrm{M}$ ammonium acetate and sequential extraction. For sequential extraction method, the metal in soil sample was separated into 6 fractions by extraction with 6 types of solution as follows: water (Fraction 1), $1 \mathrm{M}$ magnesium chloride (Fraction 2), $1 \mathrm{M}$ sodium acetate (Fraction 3 ), $0.04 \mathrm{M}$ hydroxylamine hydrochloride in $25 \%$ acetic acid (Fraction 4), $0.02 \mathrm{M}$ nitric acid, 30\% hydrogen peroxide and 3.2 $\mathrm{M}$ ammonium acetate (Fraction 5), and concentrated nitric acid (Fraction 6) [30]. The determination of the amount of the metal extracted was performed by Atomic absorption spectrometer (AAS).

\section{Statistical analysis}

All experiments were performed in triplicate. The one-way analysis of variance (ANOVA) was used to determine the statistically significant (at 95\% confidence level) difference between the 2 or more groups of data using SPSS version 23 .

\section{RESULTS AND DISCUSSION}

\section{Adsorbent characterization}

Fig. 1 presented a smooth surface of the unmodified biochar (B) and iron oxide deposition on the surface of the MB. The surface of SDS-MB became smoother (Fig. 1c) than the surface without SDS modification. Adding SDS-MB to the soil will result in the better
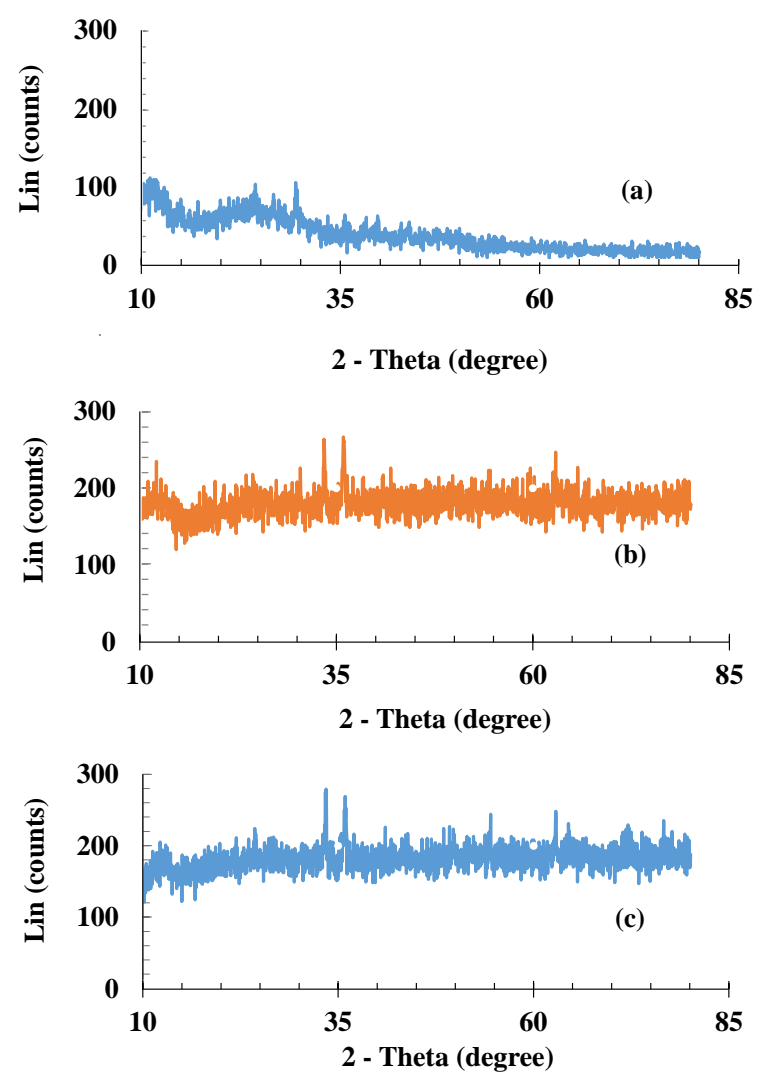

Fig. 2 XRD pattern of (a) B, (b) MB, and (c) SDS-MB.

reduction of metal movement in soil than adding $B$ due to higher porosity. SDS-MB is less porous but more negative charge on the surface than MB.

XRD pattern in Fig. 2b-c showed peaks for iron oxide at $2 \theta 3.15^{\circ}, 35.61^{\circ}, 40.9^{\circ}, 49.16^{\circ}, 54.24^{\circ}$, and $62.45^{\circ}[31]$.

\section{Effect of $\mathrm{pH}$ on adsorption and $\mathrm{pH}_{\mathrm{PZC}}$ value}

The adsorption of $10 \mathrm{mg} / 1$ synthetic wastewater was carried out using $25 \mathrm{mg}$ of $\mathrm{B}, \mathrm{MB}$, and SDS-MB. The initial solution $\mathrm{pH}$ was $2-8$, and the system temperature was $30^{\circ} \mathrm{C}$ (room temperature). Fig. 3 indicated that the opportunity of metal ions in synthetic wastewater to propagate to the adsorbed active site increased with increasing the adsorption time. For unmodified biochar (B), magnetic biochar (MB), and SDS magnetic biochar (SDS-MB), the maximum adsorption obtained when the initial solution $\mathrm{pH}$ was 8. The adsorption ability of SDS-MB was the highest. From the point of zero charge $\left(\mathrm{pH}_{\mathrm{PzC}}\right)$ determination, the charge of $\mathrm{B}, \mathrm{MB}$, and SDS-MB surface was negative when the $\mathrm{pH}$ of the solution was higher than 7.4, 3.1, and 3, respectively. When 

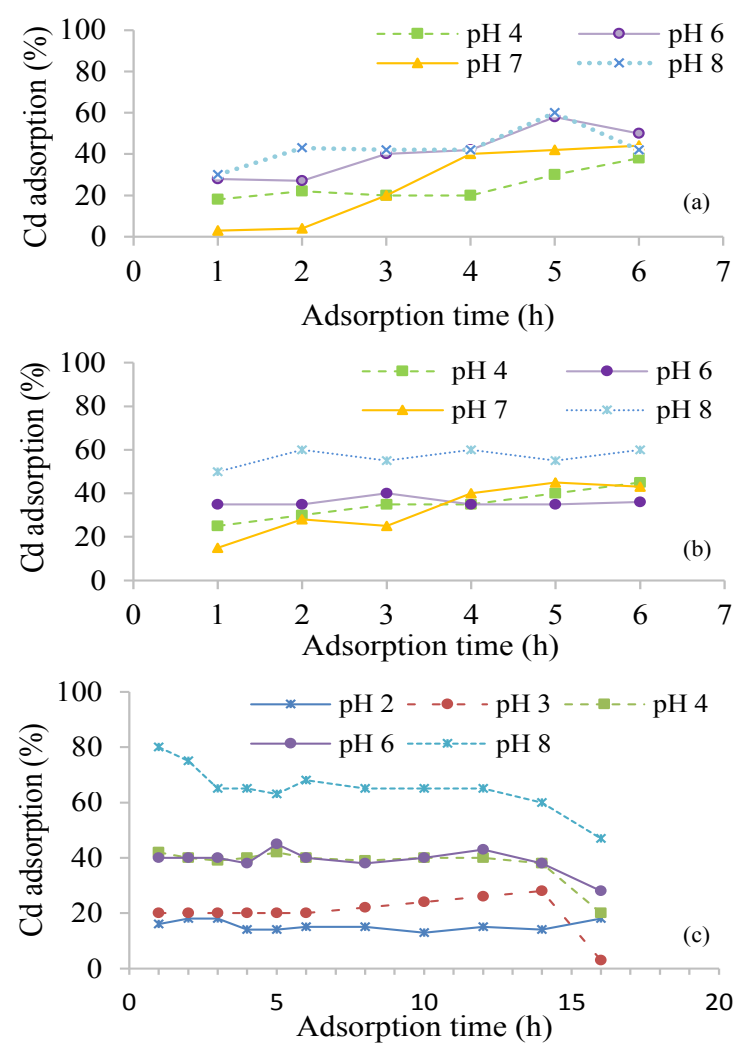

Fig. $3 \mathrm{Cd}$ removal at various solution $\mathrm{pH}$ values by (a) $\mathrm{B}$, (b) MB, and (c) SDS-MB.

Table 1 Adsorption isotherm parameters of cadmium by SDS-MB.

\begin{tabular}{lclr}
\hline \multicolumn{2}{c}{ Isotherm } & \multicolumn{2}{c}{ Isotherm } \\
\hline Langmuir & & \multicolumn{2}{c}{ Dubinin-Radushkevich } \\
$\mathrm{q}_{\max }(\mathrm{mg} / \mathrm{g})$ & 50.00 & $\mathrm{~K}_{\mathrm{Dr}}$ & $8 \times 10^{-7}$ \\
$\mathrm{~K}_{\mathrm{L}}(\mathrm{l} / \mathrm{mg})$ & 0.0016 & $\mathrm{q}_{\mathrm{D}}(\mathrm{mg} / \mathrm{g})$ & 36.97 \\
$\mathrm{R}_{\mathrm{L}}$ & 0.9843 & $\mathrm{E}(\mathrm{kJ} / \mathrm{mol})$ & 0.7906 \\
$R^{2}$ & 0.0123 & $R^{2}$ & 0.9830 \\
\hline Freundlich & & Tempkin & \\
$\mathrm{K}_{\mathrm{F}}(\mathrm{l} / \mathrm{g})$ & 7.7911 & $\mathrm{~b}_{\mathrm{o}}(\mathrm{J} / \mathrm{mol})$ & 121.95 \\
$1 / n$ & 1.0071 & $\mathrm{~A}(\mathrm{l} / \mathrm{g})$ & 1.0593 \\
$R^{2}$ & 0.9987 & $R^{2}$ & 0.9950 \\
\hline Redlich-Peterson & & & \\
$\mathrm{K}_{\mathrm{R}}(\mathrm{mg} / \mathrm{g})$ & 655 & & \\
$\mathrm{a}_{\mathrm{R}}(\mathrm{mg} / \mathrm{l})$ & 7.3434 & & \\
$\mathrm{~b}_{\mathrm{R}}$ & 0.0081 & & \\
$R^{2}$ & 0.0358 & & \\
\hline
\end{tabular}

adding SDS-MB to the study soil (pH 7.87), SDS-MB should decrease the movement of $\mathrm{Cd}$ in the soil.

\section{Adsorption isotherm study}

The consideration was on Langmuir, Freundlich, Temkin, Dubinin-Radushkevich, and RedlichPeterson isotherm to explain the adsorption. Table 1 showed the calculation results.

From Table 1, adsorption of $\mathrm{Cd}$ was in accordance with Freundlich, Temkin, and DubininRadushkevich adsorption isotherm models. An explanation from Freundlich isotherm was that the adsorption occurred on the rough and heterogeneous surface. It was a multilayer adsorption. The adsorption mechanism could be both physical and chemical processes. The value of $1 / n$ indicated that the adsorption was favorable. Temkin considered effects of some indirect adsorbent/adsorbate interactions on adsorption isotherms and suggested that because of these interactions, the heat of adsorption of all the molecules in the layer would decrease linearly with coverage. The $E$ value from DubininRadushkevich indicated that the main adsorption mechanism was the physical process. The adsorption capacity calculated by Dubinin-Radushkevich was $36.97 \mathrm{mg} / \mathrm{g}$. From all 3 isotherms, SDS-MB absorbed cadmium by absorbing cadmium into pores (the physical process) and by ion exchange of $\mathrm{Na}^{+}$ and $\mathrm{Cd}^{2+}$.

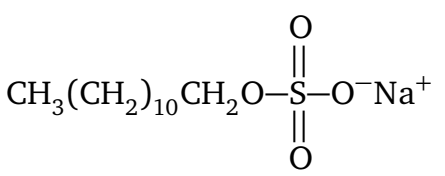

\section{Kinetic study}

The study of cadmium adsorption kinetic was by varying initial wastewater concentration and system temperature. The consideration was on pseudofirst-order and pseudo-second-order kinetic models. Table 2 presented the calculation results.

Pseudo-second-order model was a better model to explain the adsorption kinetic of SDS-MB. The chemisorption was the rate-limiting step. Cadmium ions were attached to the biochar surface by chemical bonding. The bonding may occur due to the addition of SDS to the biochar surface.

\section{Thermodynamic study}

The value of $\Delta \mathrm{H}^{\circ}, \Delta \mathrm{S}^{\circ}, \Delta \mathrm{G}^{\circ}$ at $30^{\circ} \mathrm{C}, \Delta \mathrm{G}^{\circ}$ at $45^{\circ} \mathrm{C}$, and $\Delta \mathrm{G}^{\circ}$ at $55^{\circ} \mathrm{C}$ were $6.71 \mathrm{~J} / \mathrm{mol}, 17.32 \mathrm{~J} / \mathrm{mol} . \mathrm{K}$, $-5.24 \mathrm{~kJ} / \mathrm{mol},-5.50 \mathrm{~kJ} / \mathrm{mol}$, and $-5.67 \mathrm{~kJ} / \mathrm{mol}$, respectively. The positive value of $\Delta \mathrm{H}^{\circ}$ indicated that the adsorption was an endothermic process. $\Delta \mathrm{G}^{\circ}$ was slightly lessened with the increasing temperature from $30^{\circ} \mathrm{C}$ to $55^{\circ} \mathrm{C}$. It confirmed 
Table 2 Adsorption isotherm parameters of cadmium by SDS-MB.

\begin{tabular}{lcccrrr}
\hline Concentration & \multicolumn{3}{c}{ Pseudo-first-order } & \multicolumn{3}{c}{ Pseudo-second-order } \\
\cline { 2 - 7 }$/$ temperature & $\begin{array}{c}\mathrm{K}_{1} \\
(1 / \mathrm{min})\end{array}$ & $\begin{array}{c}\mathrm{q}_{\mathrm{e}} \\
(\mathrm{mg} / \mathrm{g})\end{array}$ & $R^{2}$ & $\begin{array}{c}\mathrm{K}_{2} \\
(\mathrm{~g} / \mathrm{mg} \cdot \mathrm{min})\end{array}$ & $\begin{array}{c}\mathrm{q}_{\mathrm{e}} \\
(\mathrm{mg} / \mathrm{g})\end{array}$ & $R^{2}$ \\
\hline $10 \mathrm{mg} / 1$ & 0.0051 & 27.96 & 0.8134 & 0.0057 & 27.96 & 0.9769 \\
$20 \mathrm{mg} / 1$ & 0.0021 & 52.94 & 0.3170 & 0.0087 & 52.94 & 0.9887 \\
$30 \mathrm{mg} / 1$ & 0.0023 & 55.89 & 0.4030 & 0.0066 & 55.89 & 0.9836 \\
$40 \mathrm{mg} / 1$ & 0.0025 & 62.45 & 0.3993 & 0.0172 & 62.45 & 0.9945 \\
\hline $30^{\circ} \mathrm{C}$ & 0.0051 & 27.96 & 0.8134 & 0.0057 & 27.96 & 0.9769 \\
$45^{\circ} \mathrm{C}$ & 00106 & 7.44 & 0.2221 & 0.0037 & 7.44 & 0.7509 \\
$55^{\circ} \mathrm{C}$ & 0.0071 & 12.17 & 0.1176 & 0.0114 & 12.17 & 0.7575 \\
\hline
\end{tabular}

Table 3 Soil and SDS-MB characteristics.

\begin{tabular}{lcc}
\hline Parameter & Soil sample & SDS-MB \\
\hline Soil texture & Sandy clay loam & - \\
Moisture (\%) & 21 & - \\
$\mathrm{pH}$ & 7.87 & 3.67 \\
Electrical conductivity & 6.53 & 10.02 \\
$\quad$ (EC) (mS/cm) & & \\
Cation exchange capacity & 10.87 & 4.00 \\
(CEC) (cmol/lg) & & \\
Loss ignition $(\% \mathrm{LO})$ & 8.38 & 3.19 \\
Organic matter $(\% \mathrm{OM})$ & 3.54 & 2.97 \\
Nitrate ion (mg/kg) & 10.76 & 14.07 \\
Chloride ion $(\mathrm{mg} / \mathrm{kg})$ & 2.71 & 6.97 \\
Total phosphate $(\mathrm{mg} / \mathrm{kg})$ & 12.51 & 7.09 \\
Sulfate ion $(\mathrm{mg} / \mathrm{kg})$ & 45.28 & 4.70 \\
Aluminium ion $(\mathrm{mg} / \mathrm{kg})$ & $\mathrm{ND}$ & $\mathrm{ND}$ \\
$\mathrm{Major}^{2}$ element $(\mathrm{mg} / \mathrm{kg})$ & & \\
$\mathrm{Ca}^{2+}$ & 0.88 & 0.41 \\
$\mathrm{Mg}^{2+}$ & 80.0 & 15.8 \\
$\mathrm{~K}^{+}$ & 65.8 & 14.3 \\
$\mathrm{Cd}^{2+}$ & 0.085 & 0.039 \\
$\mathrm{ANC}^{2}$ value (meq $\left./ \mathrm{kg}\right)$ & - & 1000.3 \\
\hline
\end{tabular}

ND $=$ Not detected.

the endothermic process. The adsorption process was spontaneous at high temperatures and nonspontaneous at low temperatures due to the positive value of both $\Delta \mathrm{S}^{\circ}$ and $\Delta \mathrm{H}^{\circ}$. The negative value of $\Delta \mathrm{G}^{\circ}$ revealed that the adsorption could occur naturally.

\section{Soil and SDS-MB characteristics}

Table 3 showed soil and SDS-MB characteristics. This soil was a sandy clay loam with $72.50 \%, 5.00 \%$, and $22.50 \%$ of sand, silk, and clay, respectively. It is a moderately alkaline soil with $\mathrm{pH}$ 7.87. The CEC value is quite high. The LOI value closely relates to $\mathrm{OM}$ value. The low $\mathrm{OM}$ resulted in low metal in the form of binding to organic matter. Due to

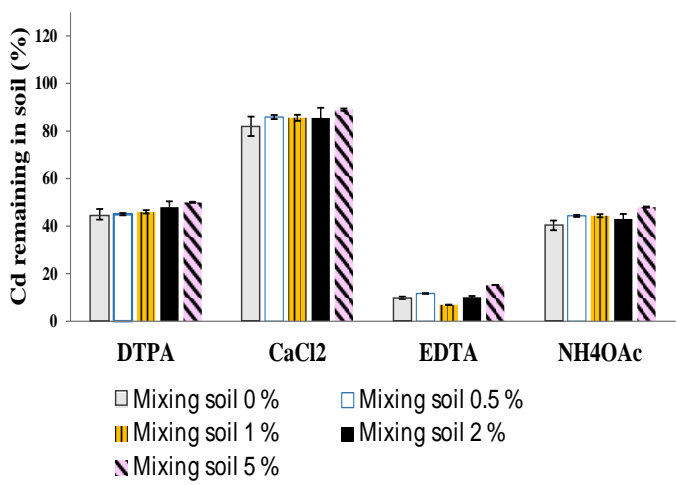

Fig. 4 Percentage of Cd remaining in soil sample after performing the single-step extraction method.

the low $\mathrm{NO}_{3}^{-}, \mathrm{Cl}^{-}, \mathrm{PO}_{4}^{3-}, \mathrm{SO}_{4}^{2-}, \mathrm{Ca}^{2+}, \mathrm{Mg}^{2+}$, and $\mathrm{K}^{+}$concentration in the soil, those ions would not affect the Cd adsorption efficiency. The SDS-MB was acidic. The OM and sulfate came from SDS. Chloride came from the addition of $\mathrm{FeCl}_{3}$. The other parameters were from water hyacinth itself. The concentration of $\mathrm{Cd}^{2+}$ was low for both soil and SDS-MB. The overall buffering capacity of material can be shown in terms of the acid neutralization capability (ANC) value. The ANC value of SDSMB was $1000.3 \mathrm{meq} / \mathrm{kg}$ which was lower than ANC value for municipal organic waste $(4280 \mathrm{meq} / \mathrm{kg}$ ) and green waste $(7100 \mathrm{meq} / \mathrm{kg})$ reported by Venegas et al [22]. Fig. 4 and Fig. 5 showed the results of the single-step extraction and sequential extraction performed after mixing contaminated soil with SDSMB.

\section{Single-step extraction and sequential extraction}

The capacity of EDTA to extract metals was higher than others, so the remaining cadmium in the soil was the lowest (Fig. 4). EDTA was able to ex- 


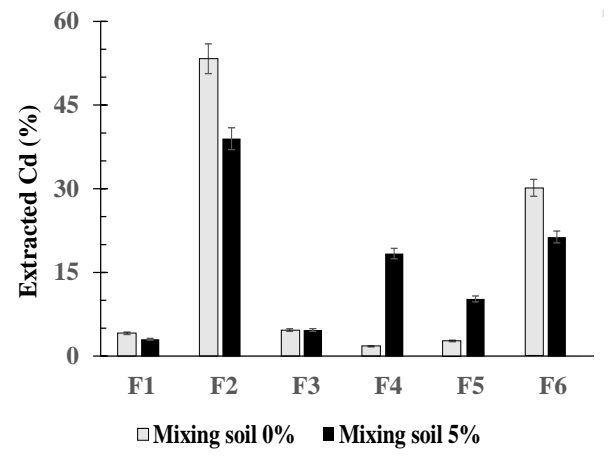

Fig. 5 Percentage of extracted cadmium using a sequential extraction method.

tract metals in a soluble form, an exchangeable form, a carbonate bound form, and partly in FeMn oxide bound form and an organically bound form [32]. Assessing the metal ability to move in the environment, EDTA solution was suitable to be used. Ammonium acetate removed metals in a soluble form and an exchangeable form from soil [33]. Extraction by ammonium acetate was highly recommended to show the exchangeability of metals. DTPA was able to extract metals in a soluble form, an exchangeable form, and partly in organically bound form. Calcium chloride $\left(\mathrm{CaCl}_{2}\right)$ removed only metals in a soluble form, so the remaining cadmium in the soil was the highest. DTPA and $\mathrm{CaCl}_{2}$ could be used to assess the phytoavailability [34]. When adding the SDS-MB to the soil at a ratio of $5 \%$, the value of remaining $\mathrm{Cd}$ in the soil was significantly different $(p<0.05)$ from the other ratios. Applying less than 5\% may not enough to decrease the movement of $\mathrm{Cd}$ in soil. The 5\% SDS-MB mixed soil showed the best ability to reduce cadmium movement in the environment and the phytoavailability. The study of a sequential extraction was carried out. In Fig. 5, Fraction 1, Fraction 2, Fraction 3, Fraction 4, Fraction 5, and Fraction 6 indicated metals in a soluble form, an exchangeable form, a form that bound to carbonate, a form that bound to oxide, a form that bound to organic matter, and a residual form, respectively.

Fig. 5 showed that metal in soil was mostly in Fraction 2 (an exchangeable form) due to the high CEC in soil. When mixing SDS-MB with soil at the ratio of 5\%, cadmium in Fractions 4 and 5 increased. The amount of iron oxide and organic matter increased when adding SDS-MB to the soil, which caused more cadmium to adhere to iron oxide and organic matter. The metal in an unstable form
$(\mathrm{F} 1+\mathrm{F} 2+\mathrm{F} 3)$ reduced, resulting in the reduction of metal movement in the soil.

\section{CONCLUSION}

The application of SDS-MB to remove cadmium from wastewater was a successful, low cost, and environmentally friendly technology. The adsorption capacity of SDS-MB was higher than unmodified biochar. The application of SDS-MB to reduce the movement of $\mathrm{Cd}$ in the contaminated soil was possible.

\section{Appendix A. Supplementary data}

Supplementary data associated with this article can be found at http://dx.doi.org/10.2306/ scienceasia1513-1874.2020.055.

Acknowledgements: Authors would like to express gratitude to KMITL Research and Innovation Services (KRIS), King Mongkut's Institute of Technology Ladkrabang for funding this research grant (KREF016009).

\section{REFERENCES}

1. Nosier SA (2003) Removal of cadmium ions from industrial wastewater by cementation. Chem Biochem Eng Q 17, 219-224.

2. Carolin CF, Kumar PS, Saravanan A, Joshiba GJ, Naushad M (2017) Efficient techniques for the removal of toxic heavy metals from aquatic environment: A review. $J$ Environ Chem Eng 5, 2782-2799.

3. Das CK, Sutar H (2012) Bio-detoxification treatment of waste water containing cadmium. Int J Eng Technol 4, 72-75.

4. Inaba T, Kobayashi E, Suwazono $\mathrm{Y}$, Uetani M, Oishi M, Nakagawa H (2005) Estimation of cumulative cadmium intake causing Itai-itai disease. Toxicol Lett 159, 192-201.

5. Raicevic S, Perovic V, Zouboulis AI (2009) Theoretical assessment of phosphate amendments for stabilization of $(\mathrm{Pb} \& \mathrm{Zn})$ in polluted soil. Waste Manage 29, 1779-1784.

6. Komarek M, Vanek A, Ettler V (2013) Chemical stabilization of metals and arsenic in contaminated soils using oxides: A review. Environ Pollut 172, 9-22.

7. Kulikowska D, Gusiatin ZM, Bulkowska K, Kierklo K (2015) Humic substances from sewage sludge compost as washing agent effectively remove $\mathrm{Cu}$ and $\mathrm{Cd}$ from soil. Chemosphere 136, 42-49.

8. Shi WS, Liu CG, Ding DH, Lei ZF, Yang YN, Feng CP, Zhang ZY (2013) Immobilization of heavy metals in sewage sludge by using subcritical water technology. Bioresour Technol 137, 18-24.

9. Téllez RT, Lopez de REM, Granado GL, Pérez EA, López RM, Guzmán JMS (2008) The water hyacinth, Eichhornia crassipes: an invasive plant in the Guadiana River Basin (Spain). Aquat Invasions 3, 42-53. 
10. Anzeze DA, Onyari JM, Shiundu PM, Gichuki JW (2014) Adsorption of $\mathrm{Pb}(\mathrm{II})$ ions from aqueous solutions by water hyacinth (Eichhornia Crassipes): Equilibrium and kinetic studies. IJEPR 2, 89-95.

11. Sarkar M, Rahman AKM, Bhoumik NC (2017) Remediation of chromium and copper on water hyacinth (E. crassipes) shoot powder. Water Resour Ind 17, 1-6.

12. Udeh NU, Nwaogazie IL, Momoh Y (2013) Bioremediation of a crude oil contaminated soil using water hyacinth (Eichhornia crassipes). Adv Appl Sci Res 4, 362-369.

13. Lehmann J (2007) A handful of carbon. Nature 446, 143-144.

14. Masto RE, Kumar S, Rout TK, Sarkar P, George J, Catena LCM (2013) Biochar from water hyacinth (Eichornia crassipes) and its impact on soil biological activity. Catena 111, 64-71.

15. Zhang F, Wang X, Yin D, Peng B, Tan C, Liu Y, Tan X, Wu S (2015) Efficiency and mechanisms of Cd removal from aqueous solution by biochar derived from water hyacinth (Eichornia crassipes). $J$ Environ Manage 153, 68-73.

16. Xu D, Zhao Y, Sun K, Gao B, Wang Z, Jin J, Zhang Z, Wang S, et al (2014) Cadmium adsorption on plantand manure-derived biochar and biochar-amended sandy soils: Impact of bulk and surface properties. Chemosphere 111, 320-326.

17. Cha JS, Park SH, Jung SC, Ryu C, Jeon JK, Shin MC, Park YK (2016) Production and utilization of biochar: A review. J Ind Eng Chem 40, 1-15.

18. Ahmed MB, Zhou JL, Ngo HH, Chen WGM (2016) Progress in the preparation and application of modified biochar for improved contaminant removal from water and wastewater. Bioresour Technol 214, 836-851.

19. Song Q, Yang B, Wang H, Xu S, Cao Y (2016) Effective removal of copper (II) and cadmium (II) by adsorbent prepared from chitosan-modified magnetic biochar. J Residuals Sci Tech 13, 197-205.

20. Cui X, Fang S, Yao Y, Li T, Ni Q, Yang X, He Z (2016) Potential mechanisms of cadmium removal from aqueous solution by Canna indica derived biochar. Sci Total Environ 562, 517-525.

21. Zheng J, Liu H, Feng H, Li W, Lam MH, Lam PK, Yu $H$ (2016) Competitive sorption of heavy metals by water hyacinth roots. Environ Pollut 219, 837-845.
22. Venegas A, Rigal A, Vidal M (2015) Viability of organic wastes and biochars as amendments for the remediation of heavy metal-contaminated soils. Chemosphere 119, 190-198.

23. Langmuir I (1916) The constitution and fundamental properties of solids and liquids. J Am Chem Soc 38, 2221-2295.

24. Freundlich H (1906) Over the adsorption in solution. $J$ Chem Phy 57, 385-471.

25. Tempkin M, Pyzhev V (1940) Kinetics of ammonia synthesis on promoted iron catalyst. Acta Phys Chim 12, 327-356.

26. Dubinin MM (1960) The potential theory of adsorption of gases and vapors for adsorbents with energetically non-uniform surface. Chem Rev 60, 235-241.

27. Toth J (1971) State equations of the solid-gas interface layers. Acta Chim Acad Sci Hung 69, 311-317.

28. Yakout SM, Elsherif E (2010) Batch kinetics, isotherm and thermodynamic studies of adsorption of strontium from aqueous solutions onto low cost rice-straw based carbons. Carbon Sci Technol 3, 144-153.

29. Miyaha Y, Lahrichib A, Idrissi M (2016) Removal of cationic dye methylene blue from aqueous solution by adsorption onto corn cob powder calcined. J Mater Environ Sci 7, 96-104.

30. Tessier A, Campbell PG, Bisson M (1979) Sequential extraction procedure for the speciation of particulate trace metals. Anal Chem 51, 844-851.

31. Han Y, Cao X, Ouyang X, Sohi SP, Chen J (2016) Adsorption kinetics of magnetic biochar derived from peanut hull on removal of $\mathrm{Cr}(\mathrm{VI})$ from aqueous solution: Effects of production conditions and particle size. Chemosphere 145, 336-341.

32. Chang YT, Hseu ZY, Zehetner F (2014) Evaluation of phytoavailability of heavy metals to Chinese cabbage (Brassica chinensis L.) in rural soils. Sci World J 2014, ID 309396.

33. Zhang MK, Liu ZY, Wang H (2010) Use of single extraction methods to predict bioavailability of heavy metals in polluted soils to rice. Commun Soil Sci Plant Anal 41, 820-831.

34. Tica D, Udovic M, Lestan D (2011) Immobilization of potentially toxic metals using different soil amendments. Chemosphere 85, 577-583. 


\section{Appendix A. Supplementary data}

Table S1 Isotherm, kinetic, and thermodynamic equations.

\begin{tabular}{|c|c|}
\hline Isotherm & Linear equation \\
\hline Langmuir [23] & $\begin{aligned} \frac{\mathrm{C}_{\mathrm{e}}}{\mathrm{q}_{\mathrm{e}}} & =\frac{\mathrm{C}_{\mathrm{e}}}{\mathrm{q}_{\mathrm{m}}}+\frac{1}{\mathrm{~K}_{\mathrm{L}} \cdot \mathrm{q}_{\mathrm{m}}} \\
\mathrm{R}_{\mathrm{L}} & =\frac{1}{1+\mathrm{K}_{\mathrm{L}} \cdot \mathrm{C}_{0}}\end{aligned}$ \\
\hline $\begin{array}{l}\text { Freundlich [24] } \\
\text { Tempkin [25] }\end{array}$ & $\begin{array}{l}\log \mathrm{q}_{\mathrm{e}}=\log \mathrm{K}_{\mathrm{f}}+\frac{1}{\mathrm{n}} \log \mathrm{C}_{\mathrm{e}} \\
\mathrm{q}_{\mathrm{e}}=\frac{\mathrm{RT}}{\mathrm{b}_{0}} \ln \mathrm{A}+\frac{\mathrm{RT}}{\mathrm{b}_{0}} \ln \mathrm{C}_{\mathrm{e}}\end{array}$ \\
\hline Dubinin-Radushkevich [26] & $\begin{array}{l}\ln \mathrm{q}_{\mathrm{e}}=\ln \mathrm{q}_{\mathrm{D}}-\mathrm{K}_{\mathrm{DR}}\left[\mathrm{RT} \ln \left(1+\frac{1}{\mathrm{C}_{\mathrm{e}}}\right)\right] \\
\mathrm{E}=\frac{1}{\sqrt{2 \mathrm{~K}}}\end{array}$ \\
\hline Redlich-Peterson [27] & $\ln \left(\mathrm{K}_{\mathrm{R}} \frac{\mathrm{C}_{\mathrm{e}}}{\mathrm{q}_{\mathrm{e}}}-1\right)=\mathrm{b}_{\mathrm{R}} \ln \mathrm{C}_{\mathrm{e}}+\ln \mathrm{a}_{\mathrm{R}}$ \\
\hline Kinetic [28] & Linear equation \\
\hline The pseudo-first-order & $\begin{array}{l}\log \left(\mathrm{q}_{\mathrm{e}}-\mathrm{q}_{\mathrm{t}}\right)=\log \mathrm{q}_{\mathrm{e}}-\mathrm{k}_{1} \frac{\mathrm{t}}{2.303} \\
\frac{1}{\mathrm{q}_{\mathrm{t}}}=\frac{1}{\mathrm{k}_{2} \mathrm{q}_{\mathrm{e}}^{2}}+\frac{\mathrm{t}}{\mathrm{q}_{\mathrm{e}}}\end{array}$ \\
\hline Thermodynamic [29] & $\begin{array}{l}\Delta \mathrm{G}^{\circ}=\Delta \mathrm{H}^{\circ}-\mathrm{T} \Delta \mathrm{S}^{\circ}=-\mathrm{RT} \ln \mathrm{K}_{\mathrm{c}} \\
\mathrm{K}_{\mathrm{c}}=\frac{\mathrm{q}_{\mathrm{e}}}{\mathrm{C}_{\mathrm{e}}} \\
\ln \mathrm{K}_{\mathrm{c}}=\frac{\Delta \mathrm{S}^{\circ}}{\mathrm{R}}-\frac{\Delta \mathrm{H}^{\circ}}{\mathrm{RT}}\end{array}$ \\
\hline
\end{tabular}

$\mathrm{q}_{\mathrm{t}}=$ the amount of adsorbed Cd per unit mass of adsorbent at time $\mathrm{t}(\mathrm{mg} / \mathrm{g})=\frac{\left(\mathrm{C}_{0}-\mathrm{C}_{\mathrm{t}}\right)}{\mathrm{W}} \mathrm{V}$.

$\mathrm{q}_{\mathrm{e}}=$ the amount of adsorbed Cd per unit mass of adsorbent at equilibrium $(\mathrm{mg} / \mathrm{g})=\frac{\left(\mathrm{C}_{0}-\mathrm{C}_{\mathrm{e}}\right)}{\mathrm{W}} \mathrm{V}$.

$\mathrm{C}_{\mathrm{t}}=$ the $\mathrm{Cd}$ concentration in solution at time $\mathrm{t}(\mathrm{mg} / \mathrm{l})$.

$\mathrm{C}_{0}=$ the initial Cd concentration in solution $(\mathrm{mg} / \mathrm{l})$.

$\mathrm{C}_{\mathrm{e}}=$ the $\mathrm{Cd}$ concentrations in solution at equilibrium (mg/l).

$\mathrm{V}=$ the volume of the solution (l).

$\mathrm{W}=$ the adsorbent mass $(\mathrm{g})$.

$\mathrm{q}_{\mathrm{m}}=$ the maximum adsorbed Cd amount per unit mass of sorbent (mg/g).

$\mathrm{K}_{\mathrm{L}}=$ Langmuir constant $(\mathrm{l} / \mathrm{mg})$.

$\mathrm{R}_{\mathrm{L}}=\mathrm{a}$ dimensionless separation factor or equilibrium parameter.

$\mathrm{K}_{\mathrm{f}}=$ Freundlich constant $(\mathrm{l} / \mathrm{g})$.

$1 / \mathrm{n}=$ the value related to the adsorption intensity.

$\mathrm{A}=$ Temkin isotherm constant $(\mathrm{l} / \mathrm{g})$ corresponding to the maximum binding energy.

$\mathrm{b}_{0}=$ Temkin constant related to heat of sorption $(\mathrm{J} / \mathrm{mol})$.

$\mathrm{R}=$ the gas constant $(8.314 \mathrm{~J} / \mathrm{mol} . \mathrm{K})$.

$\mathrm{T}=$ the absolute temperature $(\mathrm{K})$.

$\mathrm{q}_{\mathrm{D}}=$ the adsorption capacity $(\mathrm{mg} / \mathrm{g})$.

$\mathrm{K}_{\mathrm{DR}}=$ the constant related to mean free energy of adsorption per mole of the adsorbate $\left(\mathrm{mol}^{2} / \mathrm{kJ}^{2}\right)$.

$\mathrm{E}=$ the mean adsorption energy $(\mathrm{kJ} / \mathrm{mol})$ of the adsorbate.

$\mathrm{k}_{1}=$ the rate constant for pseudo-first order adsorption $(1 / \mathrm{min})$.

$\mathrm{k}_{2}=$ the rate constant for pseudo-second order adsorption $(\mathrm{g} / \mathrm{mg} \cdot \mathrm{min})$.

$\alpha=$ the initial adsorption rate (mg/g.min).

$\beta=$ the constant related to the extent of surface coverage and the activation energy for chemisorptions $(\mathrm{g} / \mathrm{mg})$.

$\mathrm{K}_{\mathrm{id}}=$ the intraparticle diffusion rate constant $\left(\mathrm{mg} / \mathrm{g} \cdot \mathrm{min}^{1 / 2}\right)$.

$\mathrm{K}_{\mathrm{c}}=$ the equilibrium constant reflected the adsorbent ability to keep the adsorbate and extent the adsorbate movement within the solution. 